\title{
Evaluation of Chloride Diffusion and Corrosion Resistance in Reinforced Concrete Using Internal Curing and Shrinkage Reducing Admixtures
}

\author{
F.J. Vázquez-Rodríguez ${ }^{1,2, *}$, A. Arato $^{2}$, Dora I. Martínez-Delgado ${ }^{2}$, A. Guzmán ${ }^{2}$, \\ N. Elizondo-Villarreal ${ }^{3}$, R. Puente-Ornelas ${ }^{2}$, Edén Rodríguez ${ }^{2}$ \\ ${ }^{1}$ Universidad Politécnica de Apodaca (UPAP); Av. Politécnica cruz con la carretera Miguel Alemán, \\ km 24.5, Col. El Barretal, C.P. 66600, Apodaca, Nuevo León, México. \\ ${ }^{2}$ Universidad Autónoma de Nuevo León, Facultad de Ingeniería Mecánica y Eléctrica, Centro de \\ Investigación y Desarrollo Tecnológico, Av. Universidad S/N, Ciudad Universitaria, C.P.66455, San \\ Nicolás de los Garza, Nuevo León, México. \\ ${ }^{3}$ Universidad Autónoma de Nuevo León, Centro de Investigación en Ciencias Físico Matemáticas, San \\ Nicolás de los Garza, N.L, 66451, México. \\ *E-mail: fcofimeuanl@gmail.com
}

doi: $10.20964 / 2018.06 .25$

Received: 1 February 2018 / Accepted: 9 March 2018 / Published: 10 May 2018

\begin{abstract}
The properties of high-performance concretes obtained by the internal curing technique were studied in the fresh and hardened states. In some of the concrete mixtures, fine normal weight aggregates were replaced with lightweight aggregates (LWA) at $20 \%$ vol. and ordinary portland cement was replaced by pulverized class $\mathrm{F}$ fly ash at $20 \%$ by mass. Additionally, some mixtures were prepared including a shrinkage-reducing admixture, either as part of the mixing water or pre-soaked into the lightweight fine aggregates. The prepared concretes were subjected to degradation tests, such as accelerated carbonation and chloride ion deterioration. In addition, the reinforced concretes were analyzed through electrochemical corrosion tests with the linear polarization resistance technique. It was found that the internally cured concretes presented a mechanical resistance similar to those reported for the reference concretes (conventional concretes), but provided a higher resistance to carbonation, rapid penetration of chloride ions, and a lower chloride ion diffusion coefficient. The reinforcing steel structure in the internally cured concretes showed lower corrosion currents $\left(\mathrm{I}_{\text {corr }}\right)$ and corrosion potentials $\left(\mathrm{E}_{\text {corr }}\right)$ in comparison to the reference concretes. Therefore, the use of the internal curing technique in concretes with pre-soaking in either water or a solution of shrinkage-reducing admixture can be considered as a viable alternative to extend the service life of concrete structures in contact with harmful environments.
\end{abstract}

Keywords: Internal curing, Shrinkage reducing admixture, Corrosion, Concrete, Chloride diffusion. 


\section{FULL TEXT}

(C) 2018 The Authors. Published by ESG (www.electrochemsci.org). This article is an open access article distributed under the terms and conditions of the Creative Commons Attribution license (http://creativecommons.org/licenses/by/4.0/). 